Article

\title{
Nutrition Related Stress Factors Reduce the Transfer of Extended-Spectrum Beta-Lactamase Resistance Genes between an Escherichia coli Donor and a Salmonella Typhimurium Recipient In Vitro
}

\author{
Eva-Maria Saliu *, Marita Eitinger, Jürgen Zentek and Wilfried Vahjen \\ Freie Universität Berlin, Institute of Animal Nutrition, Königin-Luise-Str. 49, 14195 Berlin, Germany \\ * Correspondence: Eva-Maria.Saliu@fu-berlin.de
}

Received: 25 June 2019; Accepted: 26 July 2019; Published: 31 July 2019

\begin{abstract}
The transfer of extended spectrum $\beta$-lactamase (ESBL)-genes occurs frequently between different bacteria species. The aim of this study was to investigate the impact of nutrition related stress factors on this transfer. Thus, an Escherichia coli donor and a Salmonella Typhimurium recipient were co-incubated for $4 \mathrm{~h}$ in media containing different levels of the stress factors' $\mathrm{pH}$, osmolality, copper, zinc and acetic, propionic, lactic, and n-butyric acid, as well as subtherapeutic levels of cefotaxime, sulfamethoxazole/trimethoprim, and nitrofurantoin. Conjugation frequencies were calculated as transconjugants per donor, recipient, and total bacterial count. A correction factor for the stress impact on bacterial growth was used. Acetic, lactic, and n-butyric, acid, as well as $\mathrm{pH}$, showed no significant impact. In contrast, increasing concentrations of propionate, zinc, copper, and nitrofurantoin, as well as increased osmolality reduced conjugation frequencies. Sulfamethoxazole/trimethoprim and cefotaxime showed increased transconjugants per donor, which decreased after correction for stress. This study showed, for the model mating pair, that conjugation frequencies decreased under different physiological stress conditions, and, thus, the hypothesis that stress factors may enhance conjugation should be viewed with caution. Furthermore, for studies on in vitro gene transfer, it is vital to consider the impact of studied stressors on bacterial growth.
\end{abstract}

Keywords: extended-spectrum $\beta$-lactamases; horizontal gene transfer; minerals; short-chain fatty acids; organic acids; feed additives; osmolarity; bacterial conjugation

\section{Introduction}

As extended-spectrum $\beta$-lactamase (ESBL)-producing Enterobacteriaceae (ESBL-PE) pose a major hazard on public health, the development of methods to reduce their occurrence has gained high priority [1,2]. In livestock, the highest ESBL-PE prevalence was observed in poultry with Escherichia coli being the most common species [3]. Besides comprising various pathogenic isolates, nonpathogenic E. coli isolates may also inhabit the intestinal tract of broilers as part of the commensal microbiota $[4,5]$, and ESBL-production is not correlated with virulence. Thus, normally no symptoms are observed in animals colonized by ESBL-producing E. coli (ESBL-EC). This indicates that ESBL-EC may be harmless and does not require antibiotic treatment. However, as ESBL-genes are frequently located on plasmids, which are commonly transmitted between Enterobacteriaceae [6], these plasmids can easily be transferred to pathogenic Enterobacteriaceae. This can induce the spread of antibiotic resistant pathogens in livestock.

Thus, animals may develop a disease, which is difficult to treat by antibiotics. Furthermore, treatment with $\beta$-lactam antibiotics may additionally increase the ESBL-PE load by selective pressure $[5,7,8]$. ESBL-PE transfer from livestock to humans and companion animals may occur 
via direct contact, through animal products or the environment [9-11]. In this way, humans may obtain harmless ESBL-PE, which then could transfer their ESBL-carrying plasmids to human pathogens in the hosts' intestine and lead to serious, difficult to treat infections. It has been shown that conjugation occurs and transconjugants persist for many generations independent of the selective pressure by antibiotics [12].

Bacteria, which transfer mobile genetic elements to other bacteria, are referred to as donors, while bacteria capable of acquiring the genetic information are termed recipients. Once the plasmid is successfully transferred, the recipient, harboring the 'new' plasmid, will be termed transconjugant [13]. As the number of transconjugants is negligible compared to donor and recipient counts, it is not differentiated between 'conjugated' or 'nonconjugated' recipients. When quantifying and comparing conjugation events, one frequently refers to conjugation frequency (CF) [14]. There are different ways to calculate $\mathrm{CF}$ using the donor or recipient count as reference:

$$
\text { Conjugation frequency based on donor count }(\mathrm{CF}(\mathrm{D}))=\frac{\text { Transconjugants } / m L}{\text { Donors } / m L} \text {, }
$$

[15-17].

$$
\text { Conjugation frequency based on to recipient count }(\mathrm{CF}(\mathrm{R}))=\frac{\text { Transconjugants } / m L}{\text { Recipients } / m L},
$$

[18,19]. It must be considered for studies on stress response that these methods of calculation neglect the impact of the used stressor on the growth of the different participants. This effect may give a false impression that conjugation was influenced by supplementation while the change in conjugation frequency just mirrors a change in bacterial growth. This bias may lead to wrong assumptions [14]. To avoid this misinterpretation, a different method to calculate the conjugation efficiency $(\eta)$ can be applied as

$$
\eta \approx \frac{T}{R D \Delta t}
$$

where $T$ stands for the number of transconjugants/mL, $R$ for the number of recipients $/ \mathrm{mL}, \mathrm{D}$ for the number of donors $/ \mathrm{mL}$, and $\Delta t$ represents the conjugation time in hours [14]. The impact of time on conjugation must not be underestimated, since conjugation frequencies may change dramatically within hours [20]. When calculating conjugation efficiency, the impact of $\Delta t$ on $\eta$ can be neglected due to the tremendous numeric difference between time and transconjugants, recipients, and donors. While $T$, $D$, and $R$ will range between $10^{2}$ and $10^{9}$, in most experiments the time will stay below 100 . Thus, mathematically, time differences will not be large enough to affect the result. Additionally, these results are not easily compared with the results calculated with the more traditional approach of dividing transconjugants by donor or recipient counts. Furthermore, a prerequisite for this equation is that donor and recipient concentrations remain rather constant during the period of time. This assumption does not apply for the intestinal microbiota. In the intestinal tract, bacteria undergo dynamic growth states with a constant change of the composition [21,22]. In this way, both pathogens and nonpathogenic bacteria, donors, and recipients share a timely and spatially dynamic habitat in animals. As they may interact, their growth and total amount will be influenced by environmental factors in different ways [5].

Strain dependent differences are frequently observed when conjugation trials are performed with various donor and recipient strains, as the environment and their interaction influences them differently [23]. In this sense, stress can be defined as a potential threat to the survival of the bacterial cell [24]. The mechanisms explaining the influence of stress on conjugation are manifold. Hence, stressors may influence (1) the bacterial genome, (2) number of plasmids per cell, and/or (3) efficiency of the plasmid transfer [25]. Thus, stress reactions caused by sub-lethal concentrations of antibiotics, may originate from an induction of the bacterial conjugation machinery and/or the stimulation of the excision of transferable genes from the donors' chromosome [26,27]. It was previously hypothesized, 
but not proven, that antibiotics, which affect the cell wall of bacteria, increase transfer rates [28]. Additionally, stress caused by extreme $\mathrm{pH}$, starvation, and/or organic solvents among others may influence the uptake and release of plasmids [25]. Different kinds of stressors, such as $\mathrm{pH}$, antibiotics, or nutrient starvation may induce stress and DNA mutations (SOS response) in bacteria, which can affect conjugation rates positively. Thus, conjugation under a given stress condition for one strain exemplifies the general possibility of gene transfer under these conditions.

As multi resistant bacteria rise as a problem and are a major health hazard, new reduction measurements are developed to reduce specific bacterial fractions of the intestinal microbiota in animals. Nutritional intervention steps have shown promising results to shift the microbiota towards a more desirable direction [29-34]. This may create stress for the suppressed bacteria, causing a change in their metabolic activity, including the transfer of genetic material [35-37]. Thus, modification of environmental conditions by certain feeds or feed additives can induce stress, which may threaten the survival of bacterial cells due to unfavorable conditions [36,37]. Therefore, conjugation rates may be influenced by specific feed additives such as copper and zinc, but also by bacterial metabolites (short chain fatty acids), as well as by factors defining the intestinal milieu (pH and osmolality), which may be changed by feed additives such as enzymes and pro- or prebiotics. Finally, it is known that antibiotic treatment has a tremendous impact on bacterial growth, providing a further stress factor investigated in this study [5,7].

From the considerations outlined above, this study was designed to investigate how different stress factors may affect the conjugation rates of an ESBL-producing E. coli donor strain and a Salmonella Typhimurium recipient strain. Special care was given to the analysis when referring to the donor, recipient, and total bacterial count, as well as addressing the impact of stress on bacterial growth.

\section{Materials and Methods}

\subsection{Strains and Cultivation Conditions}

A nonpathogenic E. coli isolate (ESBL10682, isolated from the excreta of one day old broilers within the RESET program), harboring the bla $a_{C T X-M-1}$ gene and belonging to the B1 subgroup, was chosen as the donor. The strain Salmonella Typhimurium L1219-R32 (isolated from pigs) was chosen as the recipient strain. This mating pair was revealed to be the best fit for the study design in a previous study obtaining conjugation kinetics for five potential E. coli donor strains and six potential Enterobacteriaceae recipients every $2 \mathrm{~h}$ for $22 \mathrm{~h}$ [38]. From these results, the mating pair was known to result in a conjugation frequency of approximately $10^{5}$ transconjugants/donor after $4 \mathrm{~h}$ of co-incubation (donor:recipient 1:1; $10^{5}$ cells/mL starting conditions) [38]. All cultures were obtained from cryo-stocks and cultured in Mueller Hinton 2 broth (Sigma-Aldrich, Chemie GmbH, Darmstadt, Germany). Culturing of the strains was done in Mueller Hinton 2 broth, supplemented with $8 \mu \mathrm{g} / \mathrm{mL}$ cefotaxime (CTX) (Alfa Aesar, Thermo Fisher GmbH, Schwerte, Germany) for E. coli incubation or $300 \mu \mathrm{g} / \mathrm{mL}$ sulfamethoxazole/trimethoprim (SXT) (Sigma-Aldrich, Chemie GmbH, Darmstadt, Germany) for the Salmonella Typhimurium strain. All strains were incubated aerobically at $37^{\circ} \mathrm{C}$.

\subsection{Experimental Design}

After the second preculture in antibiotic supplemented medium, the bacterial strains were washed twice in Phosphate Buffered Saline (PBS) (Sigma-Aldrich, Chemie GmbH, Darmstadt, Germany) and diluted to $5 \times 10^{8}$ cells $/ \mathrm{mL}$. Fifty $\mu \mathrm{L}$ of each donor and recipient strain were added to $800 \mu \mathrm{L}$ media supplemented with stress factors, as described below. After vigorous vortexing, the samples were incubated aerobically for four hours at $37^{\circ} \mathrm{C}$. The suspensions were then placed on ice, serially diluted, and spread on a MacConkey agar (Carl Roth $\mathrm{GmbH}+\mathrm{Co}$. KG, Karlsruhe, Germany) containing $8 \mu \mathrm{g}$ cefotaxime/mL and $300 \mu \mathrm{g}$ sulfamethoxazole/trimethoprim/mL to obtain transconjugants and on MacConkey agar without antibiotics to estimate the cell count of E. coli ESBL10682, Salmonella Typhimurium L1219-R32, and total bacterial count (TBC). In the set up with cefotaxime, MacConkey 
agar plates containing $8 \mu \mathrm{g}$ cefotaxime/mL, or $300 \mu \mathrm{g}$ sulfamethoxazole/trimethoprim/mL were used to obtain the cell count of E. coli ESBL10682 and Salmonella Typhimurium L1219-R32, respectively. The conjugation frequency was calculated with respect to the donor, the recipient, and the total bacterial count by dividing the number of transconjugants/mL by the respective bacteria count:

$$
\begin{aligned}
\text { Conjugation frequency based on donor count }(\mathrm{CF}(\mathrm{D})) & =\frac{\text { Transconjugants } / m L}{\text { Donor cells } / m L}, \\
\text { Conjugation frequency based on recipient count }(\mathrm{CF}(\mathrm{R})) & =\frac{\text { Transconjugants } / m L}{\text { Recipient cells } / m L}, \\
\text { Conjugation frequency based on total bacterial count }(\mathrm{CF}(\mathrm{T})) & =\frac{\text { Transconjugants } / m L}{\text { Donor }+ \text { Recipient cells } / m L} .
\end{aligned}
$$

All experiments were repeated three times with fresh cultures and with three replicates per repetition.

\subsection{Stress Factors}

For the challenge experiments, various stress factors were added to Mueller Hinton 2 broth in different concentrations. The studied stress factors were $\mathrm{pH}$, osmolality, antibiotics at subtherapeutic concentrations, zinc, copper, and the short chain fatty acids acetic, propionic, and n-butyric acid and D/L-lactate.

\subsection{1. $\mathrm{pH}$}

The impact of $\mathrm{pH} 4-7.5$ on donor and recipient growth was determined by measuring turbidity during incubation in a micro titer plate reader (Infinite200Pro, Tecan Austria GmbH, Grödig, Austria) at $690 \mathrm{~nm}$ every $5 \mathrm{~min}$ over a time period of $4 \mathrm{~h}$ (data not shown). A pH adjustment to 5.0, 5.5, 6.0, and 6.5 was carried out in a double concentrated Mueller Hinton 2 broth using 1 M hydrochloric acid ( $\mathrm{HCl})$ (Carl Roth $\mathrm{GmbH}+\mathrm{Co}$. KG, Karlsruhe, Germany). Equal volumes were achieved by adding ultrapure water to the solutions in volumetric flasks. The media were then sterile-filtered $(0.2 \mu \mathrm{m}$, VWR International GmbH, Darmstadt, Germany). Mueller Hinton 2 broth exhibited a pH value of 7.5 and served as the control.

\subsubsection{Osmolality}

Sodium chloride ( $\mathrm{NaCl}$ ) (Carl Roth $\mathrm{GmbH}+\mathrm{Co}$. KG, Karlsruhe, Germany) was added to a 50 mL Mueller Hinton 2 Medium in Afnor bottles to obtain osmolalities of 200, 300, 400, 500, 600, 700, 800,900 , and $1000 \mathrm{mOsm} / \mathrm{kg}$ and autoclaved. The correct osmolality was confirmed with a micro osmometer (type OM 806, Vogel Medizinische Technik und Elektronik, Fernwald, Germany), and the impact on bacterial growth was monitored by a turbidity measurement at $690 \mathrm{~nm}$. Correlation between osmolality and CF was analyzed using the software IBM SPSS (Version 22, IBM Deutschland $\mathrm{GmbH}$, Ehningen, Germany). The osmolality of $300 \mathrm{mOsm} / \mathrm{kg}$ served as the control, as it resembled the osmolality of the pure medium.

\subsubsection{Antibiotics}

Subtherapeutic levels of nitrofurantoin (F) (Sigma-Aldrich, Chemie GmbH, Darmstadt, Germany), cefotaxime, and sulfamethoxazole/trimethoprim were determined for the donor and recipient strains by studying their growth kinetics in the presence of different antibiotic concentrations. The impact on bacterial growth was monitored by turbidity measurement at $690 \mathrm{~nm}$, measured for $4 \mathrm{~h}$ as described above. The antibiotics were added to Mueller Hinton 2 broth at each three different concentrations $(0.4,0.5$, and $0.6 \mu \mathrm{g} \mathrm{CTX/mL;} \mathrm{1.0,} \mathrm{2.5,} \mathrm{and} 5.0 \mu \mathrm{g} \mathrm{SXT/mL;} \mathrm{2.0,} \mathrm{4.0,} \mathrm{and} 6.0 \mu \mathrm{g} \mathrm{F} / \mathrm{mL})$ while the Mueller Hinton 2 broth without antibiotics served as control. 


\subsubsection{Zinc and Copper}

Saturated solutions of zinc from $\mathrm{ZnO}$ (Sigma-Aldrich, Chemie GmbH, Darmstadt, Germany) and copper from $\mathrm{CuSO}_{4}\left(\mathrm{H}_{2} \mathrm{O}\right)_{5}$ (Merck KGaA, Darmstadt, Germany) were prepared according to Liedtke and Vahjen [39]. Atomic absorption spectroscopy (contrAA 700, Analytic Jena AG, Jena, Germany) was used to determine actual metal concentrations. The media were then serially diluted in Mueller Hinton 2 broth and donor and recipient growth was obtained by measuring turbidity at $690 \mathrm{~nm}$ for $4 \mathrm{~h}$. The concentrations (zinc: 0, 10, 21, 42, 84, $167 \mu \mathrm{g} / \mathrm{mL}$; copper: 0, 11, 22, 43, 87, $173 \mu \mathrm{g} / \mathrm{mL}$ ) were chosen due to their ability to reduce, but not inhibit, bacterial growth. Pure Mueller Hinton 2 broth served as the control.

\subsubsection{Short Chain Fatty Acids and Lactate}

Acetic acid (Carl Roth GmbH + Co. KG, Karlsruhe, Germany), propionic acid (Merck KGaA, Darmstadt, Germany), D/L-lactic acid (D/L: equal volume units, Carl Roth GmbH + Co. KG, Karlsruhe, Germany) and n-butyric acid (Sigma-Aldrich, Chemie GmbH, Darmstadt, Germany) were added to double concentrated Mueller Hinton 2 Broth. The $\mathrm{pH}$ was adjusted to $\mathrm{pH} 7.5 \mathrm{using} 5 \mathrm{M}$ sodium hydroxide $(\mathrm{NaOH})(\mathrm{Carl}$ Roth $\mathrm{GmbH}+\mathrm{Co} . \mathrm{KG}$, Karlsruhe, Germany). The dilutions were sterile-filtered $(0.2 \mu \mathrm{m})$ and the concentrations were confirmed by gas chromatography (Agilent $6890 \mathrm{~N}$, Agilent Technologies Deutschland GmbH, Waldbronn, Germany). Four different concentrations were prepared by 1:2 serial dilutions in Mueller Hinton 2 Broth (acetate, propionate, n-butyrate: 0, 18.75, 37.50, 75.00, $150.00 \mathrm{mM}$; lactate: $0,13.75,27.50,55.00,110.00 \mathrm{mM}$ ) and the exact concentrations obtained by gas chromatography. The impact on donor and recipient growth was studied prior to the conjugation experiment ). The control medium was nonsupplemented Mueller Hinton 2 Broth.

\subsection{Calculation of Stress Impact Factor}

Since stress does not only influence the conjugation but also the growth of the transconjugants, donors, and recipients, the results were corrected by a stress impact factor. This factor was defined as the percentage change of growth between the two concentrations/levels. At first, the stress impact factor (SIF), defined as the ratio between the mean colony forming units per $\mathrm{mL}$ of the control $\left(\mathrm{cfu} \mathrm{ctr}_{\mathrm{ctr}}\right)$ and a certain level of supplementation with a stress factor ( $\left.\mathrm{cfu}_{\mathrm{stress}}\right)$ was determined as

$$
\mathrm{SIF}=\frac{\frac{m e a n c f u_{\mathrm{ctr}}}{m L}}{\frac{m e a n c f u_{\mathrm{stress}}}{m L}} .
$$

Thus, SIF $=1$ would indicate no impact on the growth, SIF $>1$ shows a reduction in growth, and SIF $<1$ designates an enhanced growth when exposed to the stressor. Secondly, the growth of donors, recipients, and transconjugants were corrected $\left(\mathrm{cfu}_{\mathrm{corr}}\right)$ to the level of the controls. Thus, a condition without an impact of the stressor on bacterial growth was simulated by multiplying the $\mathrm{cfu}_{\text {stress }}$ with the SIF:

$$
\mathrm{cfu}_{\mathrm{corr}}=\mathrm{cfu}_{\mathrm{stress}} \times \mathrm{SIF} .
$$

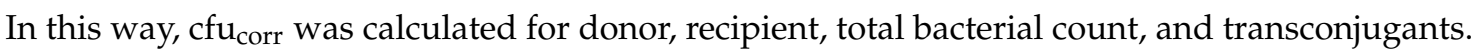
For transconjugants, SIF was calculated according to recipient growth in all cases except when cefotaxime was supplemented, since the conjugation was assumed not to transfer growth benefits in the other cases. Conjugation frequencies were subsequently calculated as described above.

\subsection{Statistics}

All statistics were calculated with the software IBM SPSS (Version 22). Results are presented as mean values \pm standard deviation. The nonparametric Kruskal-Wallis test and Mann-Whitney test were used to determine significant differences and subgroups, respectively. Differences were considered statistically significant at $p<0.05$ and $p$-values between 0.05 and 0.1 were accepted as trends. 


\section{Results}

\section{1. $p H$}

A preliminary screening of the donor and recipient growth kinetics at various $\mathrm{pH}$ values failed to detect a significant impact on the donor or recipient strains at $\mathrm{pH}$ levels of 5.0-7.5. The lowest numeric conjugation frequency was noted at an initial $\mathrm{pH}$ of 6.0 for all alternative calculations, but differences were only marginal (Table 1). Bacterial growth was not significantly affected between pH 5.0-7.5 for all incubations (Supplementary data, Figure S1, Table S2). Thus, CF values calculated acknowledging $(\mathrm{CF}(\mathrm{D})(\mathrm{SIF}), \mathrm{CF}(\mathrm{R})(\mathrm{SIF}), \mathrm{CF}(\mathrm{T})(\mathrm{SIF}))$ or neglecting $(\mathrm{CF}(\mathrm{D}), \mathrm{CF}(\mathrm{R}), \mathrm{CF}(\mathrm{T}))$ the stress impact factor are rather similar (Table 1 ).

Table 1. The impact of $\mathrm{pH}$ on the conjugation frequency $\left[\log _{10}\left(\mathrm{CF}^{1}\right)\right]$ of an Escherichia coli donor and a Salmonella Typhimurium recipient, calculated per donor, recipient, and total bacterial count corrected for the stress impact factor.

\begin{tabular}{ccccccc}
\hline $\mathbf{p H}$ & $\mathbf{C F}(\mathbf{D})$ & $\mathbf{C F}(\mathbf{R})$ & $\mathbf{C F}(\mathbf{T})$ & $\mathbf{C F}(\mathbf{D})$ (SIF) & $\mathbf{C F}(\mathbf{R})$ (SIF) & $\mathbf{C F ( T ) ~ ( S I F ) ~}$ \\
\hline 5.0 & $-5.0 \pm 0.2$ & $-4.6 \pm 0.2$ & $-5.2 \pm 0.2$ & $-5.0 \pm 0.2$ & $-4.6 \pm 0.2$ & $-5.2 \pm 0.2$ \\
5.5 & $-5.0 \pm 0.3$ & $-4.4 \pm 0.2$ & $-5.1 \pm 0.2$ & $-5.2 \pm 0.3$ & $-4.4 \pm 0.2$ & $-5.2 \pm 0.2$ \\
6.0 & $-5.2 \pm 0.4$ & $-4.6 \pm 0.2$ & $-5.3 \pm 0.4$ & $-5.3 \pm 0.4$ & $-4.6 \pm 0.2$ & $-5.4 \pm 0.4$ \\
6.5 & $-5.1 \pm 0.2$ & $-4.6 \pm 0.2$ & $-5.2 \pm 0.1$ & $-5.1 \pm 0.2$ & $-4.6 \pm 0.2$ & $-5.2 \pm 0.1$ \\
7.5 & $-5.0 \pm 0.2$ & $-4.6 \pm 0.3$ & $-5.2 \pm 0.2$ & $-5.0 \pm 0.2$ & $-4.6 \pm 0.3$ & $-5.2 \pm 0.2$ \\
\hline$p$-value & 0.672 & 0.399 & 0.627 & 0.147 & 0.399 & 0.224 \\
\hline
\end{tabular}

$1 \mathrm{CF}=$ conjugation frequency; $\mathrm{CF}(\mathrm{D})=$ transconjugants/donor; $\mathrm{CF}(\mathrm{R})=$ transconjugants/recipients; $\mathrm{CF}(\mathrm{T})=$ transconjugants/total bacterial count; SIF = stress impact factor (Supplementary Data, Table S3); for each column, $p$-values were calculated comparing CF of different levels of exposure to the stressor using the nonparametric Kruskal-Wallis test and Mann-Whitney test. Raw data are provided in supplementary data, Table S1.

\subsection{Osmolality}

The growth of Salmonella Typhimurium declined with increasing osmolality, while the E. coli strain showed the highest number of colony forming units at $500 \mathrm{mOsm} / \mathrm{L}$ (Supplementary Data, Figure S2, Table S2). Conjugation frequencies declined exponentially with increasing osmolality (correlation analyses: single, 3 parameters; $R^{2}=0.97, R^{2}=0.48$ and $R^{2}=0.96$ respectively) (Table 2 ). After correcting for stress impact on growth, the correlation of $\mathrm{CF}(\mathrm{D})$ and $\mathrm{CF}(\mathrm{T})$ with osmolality became more linear $\left(R^{2}=0.48, R^{2}=0.51\right)$. Significant differences in the CF of $0.4-0.5 \log \mathrm{cfu} / \mathrm{mL}$ were observed for all three approaches when CF was corrected by SIF (Table 2).

Table 2. The impact of osmolality on the conjugation frequency $\left[\log _{10}\left(\mathrm{CF}^{1}\right)\right]$ of an $E$. coli donor and a Salmonella Typhimurium recipient, calculated per donor, recipient, and total bacterial count corrected for the stress impact factor. The osmolality of Mueller Hinton 2 broth (control) was $300 \mathrm{mOsm} / \mathrm{kg}$.

\begin{tabular}{|c|c|c|c|c|c|c|}
\hline $\begin{array}{l}\text { Osmolality } \\
\text { (mOsm/kg). }\end{array}$ & $C F(D)$ & $\mathrm{CF}(\mathrm{R})$ & $\mathrm{CF}(\mathrm{T})$ & CF(D) (SIF) & CF(R) (SIF) & CF(T) (SIF) \\
\hline 200 & $-5.0 \pm 0.2^{\mathrm{a}}$ & $-4.7 \pm 0.3^{\mathrm{ab}}$ & $-5.2 \pm 0.2^{\mathrm{ab}}$ & $-5.2 \pm 0.2^{a b}$ & $-4.7 \pm 0.3^{a b}$ & $-5.2 \pm 0.2^{\mathrm{ab}}$ \\
\hline 300 & $-5.1 \pm 0.2^{\mathrm{a}}$ & $-4.6 \pm 0.3^{b}$ & $-5.2 \pm 0.2^{\mathrm{a}}$ & $-5.1 \pm 0.2^{a}$ & $-4.6 \pm 0.3^{b}$ & $-5.2 \pm 0.2^{\mathrm{a}}$ \\
\hline 400 & $-5.3 \pm 0.5^{a b}$ & $-4.8 \pm 0.6^{b c}$ & $-5.4 \pm 0.5^{\mathrm{ac}}$ & $-5.3 \pm 0.5^{a}$ & $-4.8 \pm 0.6^{b c}$ & $-5.4 \pm 0.5^{a c}$ \\
\hline 500 & $-5.3 \pm 0.5^{a b}$ & $-4.7 \pm 0.4 \mathrm{bc}$ & $-5.4 \pm 0.5^{\mathrm{ac}}$ & $-5.16 \pm 0.5^{\mathrm{ac}}$ & $-4.70 \pm 0.4 \mathrm{bc}$ & $-5.3 \pm 0.5^{\mathrm{acd}}$ \\
\hline 600 & $-5.6 \pm 0.7 b c$ & $-5.3 \pm 0.5^{\mathrm{a}}$ & $-5.8 \pm 0.7^{b}$ & $-5.62 \pm 0.7 b c$ & $-5.25 \pm 0.5^{\mathrm{a}}$ & $-5.7 \pm 0.7$ bcde \\
\hline 700 & $-5.6 \pm 0.1^{c}$ & $-5.2 \pm 0.4^{\mathrm{a}}$ & $-5.8 \pm 0.1^{b}$ & $-5.53 \pm 0.2^{b d}$ & $-5.20 \pm 0.4^{a}$ & $-5.7 \pm 0.3^{\mathrm{e}}$ \\
\hline 800 & $-5.8 \pm 0.4^{c}$ & $-4.9 \pm 0.5^{a b c}$ & $-5.8 \pm 0.4^{a b c}$ & $-5.52 \pm 0.4 \mathrm{bd}$ & $-4.93 \pm 0.5^{a b c}$ & $-5.7 \pm 0.4$ bce \\
\hline 900 & $-5.7 \pm 0.2^{c}$ & $-4.8 \pm 0.1^{a b c}$ & $-5.8 \pm 0.1^{a b c}$ & $-5.25 \pm 0.2 \mathrm{abc}$ & $-4.76 \pm 0.1^{a b c}$ & $-5.4 \pm 0.2$ abcde \\
\hline 1000 & $-5.7 \pm 0.1^{c}$ & $-5.0 \pm 0.3^{b c}$ & $-5.8 \pm 0.1 \mathrm{bc}$ & $-5.57 \pm 0.1 \mathrm{bd}$ & $-4.96 \pm 0.3 b c$ & $-5.7 \pm 0.1$ be \\
\hline$p$-value & $<0.001$ & 0.019 & $<0.001$ & 0.005 & 0.019 & 0.003 \\
\hline
\end{tabular}

1 Conjugation frequency (CF) calculated as CF/D = transconjugants/donor, $\mathrm{CF} / \mathrm{R}=$ transconjugants/recipients or $\mathrm{CF} / \mathrm{T}=$ transconjugants/total bacterial count; SIF = stress impact factor (Supplementary Data, Table S3); $p$-values were calculated comparing CF of different levels of exposure to the stressor using the nonparametric Kruskal-Wallis test and Mann-Whitney test. Significant differences $(p \leq 0.05)$ between values are indicated by different superscript letters. Raw data are provided in supplementary data, Table S1. 


\subsection{Antibiotics}

Cefotaxime had a relatively strong negative impact on the growth of the recipient strain, causing a reduction of $1.8 \log \mathrm{cfu} / \mathrm{mL}$, when no supplementation was compared to the highest CTX concentration of $0.6 \mu \mathrm{g} / \mathrm{mL}$. The donor strain was less sensitive towards the substance, resulting in a reduction of $1.2 \log \mathrm{cfu} / \mathrm{mL}$ from the control to $0.6 \mu \mathrm{g}$ CTX/mL (Supplementary data, Figure S3, Table S2). When challenged with subtherapeutic concentrations of cefotaxime, the conjugation frequencies showed an increasing trend $(p=0.06)$, with increasing concentrations of CTX when calculated based on donor count. This effect was profound for $\mathrm{CF}(\mathrm{R})$ and $\mathrm{CF}(\mathrm{T})$ (Table 3). When corrected for the stress impact factor, a significant difference was observed for $0.4 \mu \mathrm{g} C \mathrm{CX} / \mathrm{mL}$ supplementation in $\mathrm{CF}(\mathrm{D})(\mathrm{SIF})$ and $\mathrm{CF}(\mathrm{T})(\mathrm{SIF})$, while $\mathrm{CF}(\mathrm{R})(\mathrm{SIF})$ showed no significant differences.

Increasing concentrations of sulfamethoxazole/trimethoprim decreased the growth of the donor strain by $1.8 \log$, while the growth of the recipient strain only increased with $0.2 \log$ from no to $5 \mu \mathrm{g}$ SXT/mL supplementation (Supplementary data, Figure S4, Table S2). Furthermore, a strong impact on conjugation frequencies relating to donor, recipient, and total bacterial count was observed (Table 3). While the conjugation frequency increased significantly for 2.5 and $5.0 \mu \mathrm{g} \mathrm{SXT} / \mathrm{mL}$ when based on the donor strain, it decreased significantly when referring to recipient and total bacterial cell growth. When corrected for the stress impact on bacterial growth, a significant decrease was observed for $\mathrm{CF}(\mathrm{D})(\mathrm{SIF}), \mathrm{CF}(\mathrm{R})(\mathrm{SIF})$, and $\mathrm{CF}(\mathrm{T})(\mathrm{SIF})$ between the control and the highest SXT concentration with 1.3, 0.9 , and $1.2 \mathrm{log}$, respectively (Table 3 ).

Donor and recipient growth declined in a dose-dependent fashion at 0.7 and $0.8 \log \mathrm{cfu} / \mathrm{mL}$, respectively, with increasing concentrations of nitrofurantoin (Supplementary Data, Figure S5, Table S2). Similarly, conjugation frequencies $(\mathrm{CF}(\mathrm{D}), \mathrm{CF}(\mathrm{T})$, and $\mathrm{CF}(\mathrm{D})$ ) were significantly affected by the supplementation of $6.0 \mu \mathrm{g} \mathrm{F} / \mathrm{mL}$ (Table 3). This effect was slightly increased when the stress impact on bacterial growth was considered. Overall, the decrease in CF ranged from 1.3 to $1.5 \log$.

Table 3. The impact of subtherapeutic levels of antibiotics on conjugation frequency $\left[\log _{10}\left(\mathrm{CF}^{1}\right)\right]$ of an E. coli donor and a Salmonella Typhimurium recipient, calculated per donor, recipient and total bacterial count corrected for the stress impact factor.

\begin{tabular}{|c|c|c|c|c|c|c|}
\hline $\begin{array}{c}\text { Antibiotic }^{2} \\
(\mu \mathrm{g} / \mathrm{mL})\end{array}$ & $\mathrm{CF}(\mathrm{D})$ & $\mathrm{CF}(\mathrm{R})$ & $\mathrm{CF}(\mathrm{T})$ & $\mathrm{CF}(\mathrm{D})$ (SIF) & CF(R) (SIF) & $\mathrm{CF}(\mathrm{T})$ (SIF) \\
\hline \multicolumn{7}{|l|}{ CTX } \\
\hline 0 & $-4.9 \pm 0.5$ & $-4.3 \pm 0.6^{\mathrm{a}}$ & $-5.0 \pm 0.5^{\mathrm{a}}$ & $-4.9 \pm 0.5^{\mathrm{a}}$ & $-4.3 \pm 0.6$ & $-5.0 \pm 0.7^{\mathrm{a}}$ \\
\hline 0.4 & $-4.4 \pm 0.7$ & $-3.0 \pm 0.6^{b}$ & $-4.4 \pm 0.7^{b}$ & $-5.6 \pm 0.5^{b}$ & $-4.9 \pm 0.6$ & $-5.7 \pm 0.4^{b}$ \\
\hline 0.5 & $-4.1 \pm 0.7$ & $-2.9 \pm 1.0^{b}$ & $-4.1 \pm 0.7^{b}$ & $-5.0 \pm 0.6^{\mathrm{a}}$ & $-5.0 \pm 0.7$ & $-5.3 \pm 0.6^{\mathrm{ab}}$ \\
\hline 0.6 & $-4.2 \pm 0.5$ & $-2.6 \pm 0.9^{b}$ & $-4.2 \pm 0.5^{b}$ & $-4.7 \pm 0.5^{\mathrm{a}}$ & $-4.7 \pm 0.6$ & $-5.0 \pm 0.5^{\mathrm{a}}$ \\
\hline$p$-value & 0.060 & 0.002 & 0.002 & 0.011 & 0.163 & 0.021 \\
\hline \multicolumn{7}{|l|}{ SXT } \\
\hline 0 & $-4.9 \pm 0.5^{\mathrm{ab}}$ & $-4.3 \pm 0.6^{\mathrm{a}}$ & $-5.0 \pm 0.5^{\mathrm{a}}$ & $-4.9 \pm 0.5^{\mathrm{a}}$ & $-4.3 \pm 0.6^{a}$ & $-5.0 \pm 0.5^{\mathrm{a}}$ \\
\hline 1.0 & $-5.6 \pm 0.9$ ac & $-5.9 \pm 0.7^{b}$ & $-6.1 \pm 0.7^{b}$ & $-6.9 \pm 0.9^{b}$ & $-5.9 \pm 0.7^{b}$ & $-6.6 \pm 0.8^{b}$ \\
\hline 2.5 & $-4.3 \pm 0.3^{b}$ & $-5.3 \pm 0.4^{b}$ & $-5.3 \pm 0.4^{\mathrm{ab}}$ & $-5.7 \pm 0.4^{\mathrm{ab}}$ & $-5.3 \pm 0.4^{b}$ & $-5.9 \pm 0.4^{b}$ \\
\hline 5.0 & $-4.1 \pm 0.4^{\mathrm{c}}$ & $-5.6 \pm 0.5^{b}$ & $-5.6 \pm 0.5^{b}$ & $-6.2 \pm 0.4^{b}$ & $-5.6 \pm 0.5^{b}$ & $-6.2 \pm 0.5^{b}$ \\
\hline $\begin{array}{c}p \text {-value } \\
\mathbf{F}\end{array}$ & 0.001 & 0.001 & 0.017 & $<0.001$ & 0.001 & 0.001 \\
\hline 0 & $-4.9 \pm 0.5^{\mathrm{a}}$ & $-4.3 \pm 0.6^{\mathrm{a}}$ & $-5.0 \pm 0.7^{\mathrm{a}}$ & $-4.9 \pm 0.5^{\mathrm{a}}$ & $-4.3 \pm 0.6^{\mathrm{a}}$ & $-5.0 \pm 0.5^{\mathrm{a}}$ \\
\hline 2.0 & $-5.2 \pm 0.5^{\mathrm{a}}$ & $-4.6 \pm 0.5^{\mathrm{a}}$ & $-5.3 \pm 0.4^{\mathrm{a}}$ & $-4.8 \pm 0.7^{a}$ & $-4.5 \pm 0.5^{\mathrm{a}}$ & $-5.0 \pm 0.6^{\mathrm{a}}$ \\
\hline 4.0 & $-5.2 \pm 0.5^{\mathrm{a}}$ & $-4.6 \pm 0.3^{\mathrm{a}}$ & $-5.3 \pm 0.5^{\mathrm{a}}$ & $-4.9 \pm 0.3^{a}$ & $-4.5 \pm 0.4^{\mathrm{a}}$ & $-5.1 \pm 0.3^{a}$ \\
\hline 6.0 & $-6.2 \pm 0.7^{b}$ & $-5.8 \pm 0.8^{b}$ & $-6.4 \pm 0.7^{b}$ & $-6.3 \pm 0.6^{b}$ & $-5.8 \pm 0.8^{b}$ & $-6.4 \pm 0.7^{b}$ \\
\hline$p$-value & 0.002 & 0.001 & 0.001 & 0.001 & 0.001 & 0.001 \\
\hline
\end{tabular}

${ }^{1}$ Conjugation frequency $(\mathrm{CF})$ calculated as $\mathrm{CF} / \mathrm{D}=$ transconjugants/donor, $\mathrm{CF} / \mathrm{R}=$ transconjugants/recipients or $\mathrm{CF} / \mathrm{T}=$ transconjugants/total bacterial count; SIF = stress impact factor (Supplementary Data, Table S3); 2CTX = cefotaxime; SXT = sulfamethoxazole/trimethoprim; $\mathrm{F}=$ nitrofurantoin; $p$-values were calculated comparing $\mathrm{CF}$ of different levels of exposure to the stressor using the nonparametric Kruskal-Wallis test and Mann-Whitney test. Significant differences $(p \leq 0.05)$ between values are indicated by different superscript letters. Raw data are provided in supplementary data, Table S1. 


\subsection{Zinc and Copper}

The normal growth of E. coli ESBL10682 was not affected significantly by zinc supplementation, while Salmonella Typhimurium L1219-R32 declined by $0.6 \log \mathrm{cfu} / \mathrm{mL}$ at the highest investigated zinc concentration compared to the controls (Supplementary data, Figure S7, Table S2). The opposite occurred when copper was supplemented. While the recipient strain was not significantly influenced, the growth of the donor decreased with $1.5 \log \mathrm{cfu} / \mathrm{mL}$ (Supplementary Data, Figure S6, Table S2). Values for the conjugation frequency declined with higher concentrations of zinc and copper. Zinc concentrations of 321 and $642 \mu \mathrm{M}$ resulted in a slight but significant decrease when CF referred to recipient counts (Table 4). When corrected for the SIF, this effect was observed for CF(D)(SIF), CF(R)(SIF), as well as $\mathrm{CF}(\mathrm{T})(\mathrm{SIF})$. Copper supplementation decreased $\mathrm{CF}(\mathrm{D}), \mathrm{CF}(\mathrm{R})$, and $\mathrm{CF}(\mathrm{T})$ significantly by 1.1, 3.2, and $2.3 \log \mathrm{cfu} / \mathrm{mL}$, respectively. A correction for the stress impact on bacterial growth showed even more severe reductions of 3.1,3.2, and $3.2 \log \mathrm{cfu} / \mathrm{mL}$, respectively (Table 4, Figure 1).

Table 4. The influence of zinc and copper on conjugation frequency $\left[\log _{10}\left(\mathrm{CF}^{1}\right)\right]$ of an $E$. coli donor and a Salmonella Typhimurium recipient, calculated per donor, recipient, and total bacterial count corrected for the stress impact factor.

\begin{tabular}{|c|c|c|c|c|c|c|}
\hline Minerals $^{2}(\mu \mathrm{M})$ & CF(D) & $\mathrm{CF}(\mathrm{R})$ & $\mathrm{CF}(\mathrm{T})$ & CF(D) (SIF) & $\mathrm{CF}(\mathrm{R})(\mathrm{SIF})$ & CF(T) (SIF) \\
\hline \multicolumn{7}{|l|}{ Zinc } \\
\hline 0 & $-5.3 \pm 0.5$ & $-4.2 \pm 0.5^{\mathrm{a}}$ & $-5.4 \pm 0.5$ & $-5.3 \pm 0.5^{\mathrm{a}}$ & $-4.2 \pm 0.5^{\mathrm{a}}$ & $-5.4 \pm 0.5^{\mathrm{a}}$ \\
\hline 153 & $-5.2 \pm 0.3$ & $-4.5 \pm 0.2^{\mathrm{ab}}$ & $-5.3 \pm 0.3$ & $-5.7 \pm 0.3^{\mathrm{ab}}$ & $-4.5 \pm 0.2^{a b}$ & $-5.7 \pm 0.3^{\mathrm{ab}}$ \\
\hline 321 & $-5.7 \pm 0.7$ & $-5.0 \pm 0.5^{b c}$ & $-5.8 \pm 0.6$ & $-6.1 \pm 0.7^{b c}$ & $-5.0 \pm 0.5^{b c}$ & $-6.1 \pm 0.6^{b c d}$ \\
\hline 642 & $-5.6 \pm 0.4$ & $-4.9 \pm 0.5^{b c}$ & $-5.7 \pm 0.4$ & $-6.1 \pm 0.4^{b c}$ & $-4.9 \pm 0.5^{b c}$ & $-6.2 \pm 0.4^{c}$ \\
\hline 1285 & $-5.4 \pm 0.4$ & $-4.4 \pm 0.1^{\mathrm{ab}}$ & $-5.5 \pm 0.3$ & $-5.7 \pm 0.3^{a b c}$ & $-4.4 \pm 0.1^{\mathrm{ab}}$ & $-5.6 \pm 0.3^{a b d}$ \\
\hline 2554 & $-5.5 \pm 0.2$ & $-4.4 \pm 0.3^{\mathrm{ab}}$ & $-5.6 \pm 0.2$ & $-5.5 \pm 0.2^{\mathrm{ab}}$ & $-4.4 \pm 0.3^{a b}$ & $-5.6 \pm 0.2^{\mathrm{ab}}$ \\
\hline$p$-value & 0.281 & -0.015 & -0.192 & 0.006 & 0.015 & 0.002 \\
\hline \multicolumn{7}{|l|}{ Copper } \\
\hline 0 & $-5.3 \pm 0.5^{\mathrm{a}}$ & $-4.2 \pm 0.5^{\mathrm{a}}$ & $-5.4 \pm 0.5^{\mathrm{a}}$ & $-5.3 \pm 0.5^{a}$ & $-4.2 \pm 0.5^{\mathrm{a}}$ & $-5.4 \pm 0.5^{\mathrm{a}}$ \\
\hline 173 & $-5.0 \pm 0.2^{\mathrm{a}}$ & $-4.2 \pm 0.2^{\mathrm{a}}$ & $-5.0 \pm 0.2^{\mathrm{a}}$ & $-5.5 \pm 0.2^{a b}$ & $-4.2 \pm 0.2^{\mathrm{a}}$ & $-5.5 \pm 0.2^{\mathrm{ab}}$ \\
\hline 346 & $-4.9 \pm 0.6^{a}$ & $-4.5 \pm 0.8^{a}$ & $-5.0 \pm 0.6^{a}$ & $-5.7 \pm 0.6^{\mathrm{ab}}$ & $-4.5 \pm 0.8^{a}$ & $-5.7 \pm 0.6^{a b}$ \\
\hline 677 & $-5.2 \pm 0.4^{\mathrm{a}}$ & $-5.1 \pm 0.8^{a}$ & $-5.6 \pm 0.5^{a}$ & $-6.3 \pm 0.4^{b c}$ & $-5.1 \pm 0.8^{a}$ & $-6.4 \pm 0.5^{b c}$ \\
\hline 1369 & $-6.4 \pm 0.9^{b}$ & $-6.9 \pm 1.0^{b}$ & $-7.2 \pm 0.8^{b}$ & $-8.0 \pm 1.1^{\mathrm{cd}}$ & $-6.9 \pm 1.0^{b}$ & $-8.0 \pm 1.0^{\mathrm{cd}}$ \\
\hline 2722 & $-6.5 \pm 0.7^{b}$ & $-7.4 \pm 0.9^{b}$ & $-7.7 \pm 0.7^{b}$ & $-8.4 \pm 0.9^{d}$ & $-7.4 \pm 0.9^{b}$ & $-8.6 \pm 0.9^{d}$ \\
\hline$p$-value & $<0.001$ & $<0.001$ & $<0.001$ & $<0.001$ & $<0.001$ & $<0.001$ \\
\hline
\end{tabular}

${ }^{1}$ Conjugation frequency $(\mathrm{CF})$ calculated as $\mathrm{CF} / \mathrm{D}=$ transconjugants/donor, $\mathrm{CF} / \mathrm{R}=$ transconjugants/recipients or $\mathrm{CF} / \mathrm{T}=$ transconjugants/total bacterial count; $\mathrm{SIF}=$ stress impact factor,${ }^{2}$ concentrations are referring to elemental zinc and copper; $p$-values were calculated comparing CF of different levels of exposure to the stressor using the nonparametric Kruskal-Wallis test and Mann-Whitney test. Significant differences $(p \leq 0.05)$ between values are indicated by different superscript letters. Raw data are provided in supplementary data, Table S1. 

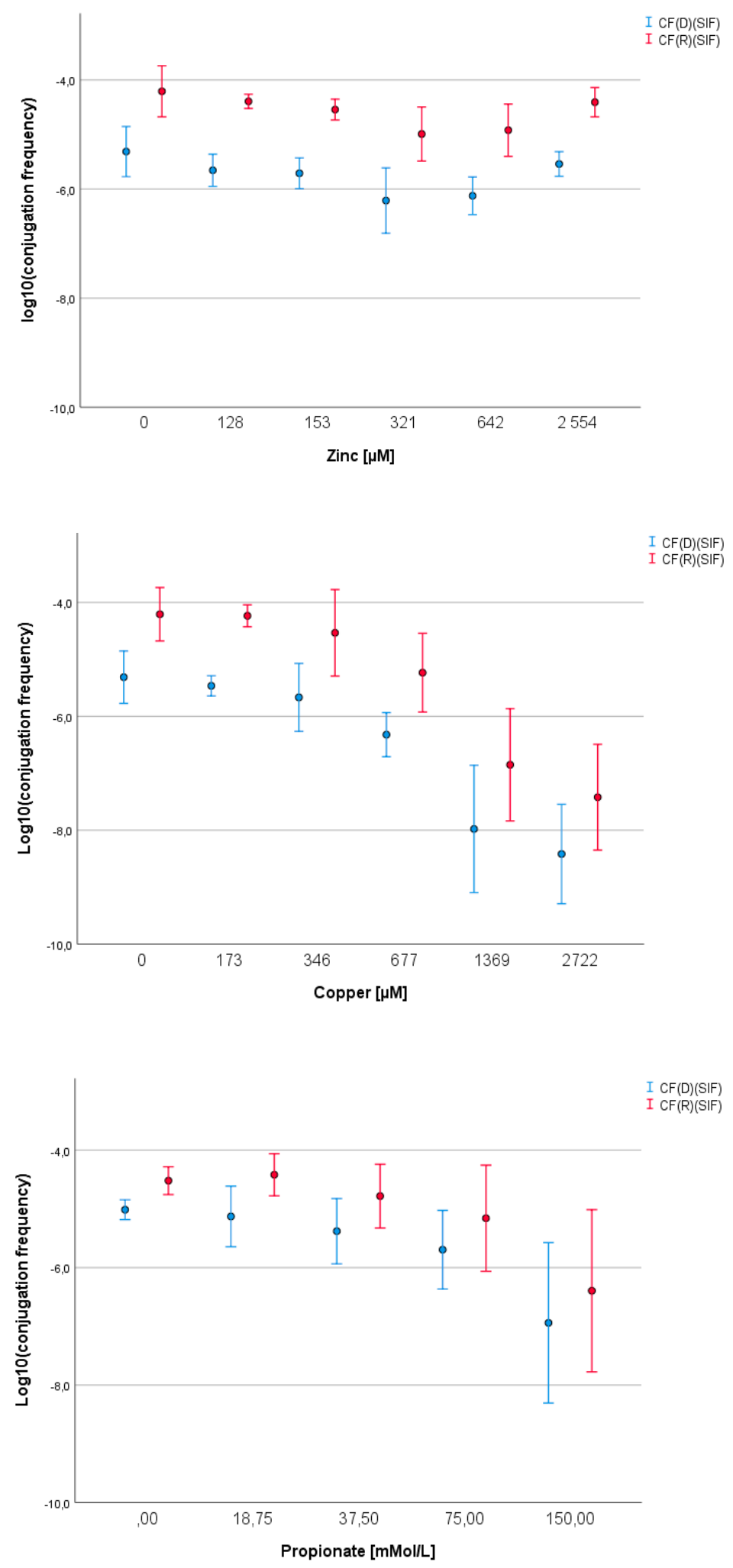

Figure 1. The impact of different concentrations of zinc, copper, and propionate on conjugation frequency of an E. coli donor and a Salmonella Typhimurium recipient after correction for the stress impact on bacterial growth. Mean values and standard deviations are displayed for conjugation frequencies $(\mathrm{CF})$ calculated as $\mathrm{CF}(\mathrm{D})=$ transconjugants/donor or $\mathrm{CF}(\mathrm{R})=$ transconjugants/recipients; SIF $=$ stress impact factor. 


\subsection{Short Chain Fatty Acids}

The highest negative impact on the growth of both strains was observed in the presence of propionic acid with a decrease of 0.6 and $0.5 \log$ units for the donor and recipient strains, respectively (Supplementary Data, Figure S10, Table S2). Acetic and n-butyric acid reduced bacterial growth by approximately 0.2 and $0.4 \log$ units, respectively (Supplementary Data, Figure S8, Figure S11, Table S2). In the presence of lactic acid, the growth of both donor and recipient strains remained rather constant (Supplementary Data, Figure S9, Table S2). Similarly, n-butyric and lactic acid had no significant impact on conjugation frequencies (Table 5). However, supplementation of media with acetic or propionic acid led to a significantly negative impact on conjugation events. Thus, acetic acid showed significantly lower CF(D)-values, but after correction for SIF, this effect disappeared (Table 5). Propionic acid supplementation, on the other hand, led to decreasing conjugation frequencies for $C F(D), C F(R)$, and $\mathrm{CF}(\mathrm{T})$ with $0.6,0.5$, and $0.7 \log$ (Figure 1). A correction for SIF resulted in a sharper decrease with $0.8 \log \mathrm{cfu} / \mathrm{mL}$ for both $\mathrm{CF}(\mathrm{D})(\mathrm{SIF})$ and $\mathrm{CF}(\mathrm{T})(\mathrm{SIF})$, considering the difference between control and highest propionic acid concentration (Table 5).

Table 5. Influence of bacterial metabolites on conjugation frequency $\left[\log _{10}\left(\mathrm{CF}^{1}\right)\right]$ of an $E$. coli donor and a Salmonella Typhimurium recipient, calculated per donor, recipient, and total bacterial count corrected for the stress impact factor.

\begin{tabular}{|c|c|c|c|c|c|c|}
\hline $\begin{array}{c}\text { Organic } \\
\text { acid (mM) }\end{array}$ & $\mathrm{CF}(\mathrm{D})$ & $\mathrm{CF}(\mathrm{R})$ & $\mathrm{CF}(\mathrm{T})$ & CF(D) (SIF) & $\mathrm{CF}(\mathrm{R})$ (SIF) & $\mathrm{CF}(\mathrm{T})$ (SIF) \\
\hline \multicolumn{7}{|l|}{ Acetate } \\
\hline 0 & $-5 . \pm 0.2^{\mathrm{a}}$ & $-4.5 \pm 0.2$ & $-5.1 \pm 0.2$ & $-5.0 \pm 0.2$ & $-4.5 \pm 0.2$ & $-5.1 \pm 0.2$ \\
\hline 37 & $-5.0 \pm 0.4^{\mathrm{ab}}$ & $-4.3 \pm 0.5$ & $-5.1 \pm 0.4$ & $-5.0 \pm 0.4$ & $-4.3 \pm 0.5$ & $-5.1 \pm 0.4$ \\
\hline 74 & $-5.0 \pm 0.2^{\mathrm{ac}}$ & $-4.2 \pm 0.6$ & $-5.1 \pm 0.2$ & $-4.9 \pm 0.1$ & $-4.2 \pm 0.6$ & $-5.0 \pm 0.1$ \\
\hline 111 & $-5.5 \pm 0.6^{b}$ & $-4.6 \pm 0.8$ & $-5.6 \pm 0.6$ & $-5.4 \pm 0.6$ & $-4.6 \pm 0.8$ & $-5.5 \pm 0.6$ \\
\hline 148 & $-5.5 \pm 0.6^{b c}$ & $-4.8 \pm 0.3$ & $-5.6 \pm 0.5$ & $-5.3 \pm 0.6$ & $-4.8 \pm 0.3$ & $-5.4 \pm 0.5$ \\
\hline$p$-value & 0.036 & 0.231 & 0.069 & 0.239 & 0.231 & 0.168 \\
\hline \multicolumn{7}{|l|}{ Propionate } \\
\hline 0 & $-5.0 \pm 0.2^{\mathrm{a}}$ & $-4.5 \pm 0.3^{a}$ & $-5.1 \pm 0.2^{\mathrm{a}}$ & $-5.0 \pm 0.2^{\mathrm{a}}$ & $-4.5 \pm 0.3^{a}$ & $-5.1 \pm 0.2^{a b}$ \\
\hline 36 & $-5.1 \pm 0.5^{\mathrm{a}}$ & $-4.4 \pm 0.4^{\mathrm{a}}$ & $-5.1 \pm 0.5^{\mathrm{a}}$ & $-5.1 \pm 0.5^{\mathrm{a}}$ & $-4.4 \pm 0.4^{\mathrm{a}}$ & $-5.0 \pm 0.5^{b}$ \\
\hline 73 & $-5.5 \pm 0.6^{\mathrm{ab}}$ & $-4.8 \pm 0.5^{\mathrm{a}}$ & $-5.6 \pm 0.5^{b}$ & $-5.4 \pm 0.6^{\mathrm{a}}$ & $-4.8 \pm 0.5^{a}$ & $-5.5 \pm 0.5^{\mathrm{ac}}$ \\
\hline 109 & $-5.6 \pm 0.7^{a b}$ & $-5.2 \pm 0.9^{a b}$ & $-5.7 \pm 0.8^{a b}$ & $-5.6 \pm 0.7^{\mathrm{ab}}$ & $-5.2 \pm 0.9^{a b}$ & $-5.7 \pm 0.8 \mathrm{ac}$ \\
\hline 145 & $-6.8 \pm 1.4^{b}$ & $-6.2 \pm 1.5^{b}$ & $-6.9 \pm 1.4^{b}$ & $-6.9 \pm 1.4^{b}$ & $-6.2 \pm 1.5^{b}$ & $-7.1 \pm 1.4^{\mathrm{c}}$ \\
\hline$p$-value & 0.002 & 0.006 & $<0.001$ & $<0.001$ & 0.006 & $<0.001$ \\
\hline \multicolumn{7}{|l|}{$\mathrm{D} / \mathrm{L}$-Lactate } \\
\hline 0 & $-5.0 \pm 0.2$ & $-4.6 \pm 0.2$ & $-5.1 \pm 0.2$ & $-5.0 \pm 0.2$ & $-4.6 \pm 0.2$ & $-5.1 \pm 0.2$ \\
\hline 29 & $-5.0 \pm 0.3$ & $-4.7 \pm 0.2$ & $-5.1 \pm 0.4$ & $-5.1 \pm 0.3$ & $-4.7 \pm 0.2$ & $-5.3 \pm 0.2$ \\
\hline 57 & $-5.2 \pm 0.4$ & $-4.7 \pm 0.4$ & $-5.4 \pm 0.4$ & $-5.2 \pm 0.4$ & $-4.7 \pm 0.4$ & $-5.3 \pm 0.4$ \\
\hline 86 & $-5.0 \pm 0.3$ & $-4.6 \pm 0.4$ & $-5.2 \pm 0.4$ & $-5.0 \pm 0.3$ & $-4.6 \pm 0.4$ & $-5.1 \pm 0.4$ \\
\hline 114 & $-5.0 \pm 0.3$ & $-4.6 \pm 0.2$ & $-5.2 \pm 0.3$ & $-5.1 \pm 0.3$ & $-4.6 \pm 0.2$ & $-5.2 \pm 0.3$ \\
\hline$p$-value & 0.689 & 0.440 & 0.474 & 0.609 & 0.749 & 0.338 \\
\hline \multicolumn{7}{|l|}{ n-Butyrate } \\
\hline 0 & $-5.0 \pm 0.2$ & $-4.5 \pm 0.3$ & $-5.1 \pm 0.2$ & $-5.0 \pm 0.2$ & $-4.5 \pm 0.2$ & $-5.1 \pm 0.2$ \\
\hline 38 & $-5.1 \pm 0.4$ & $-4.2 \pm 0.7$ & $-5.1 \pm 0.4$ & $-5.0 \pm 0.4$ & $-4.2 \pm 0.4$ & $-4.9 \pm 0.4$ \\
\hline 76 & $-5.0 \pm 0.4$ & $-4.3 \pm 0.2$ & $-5.1 \pm 0.4$ & $-5.0 \pm 0.3$ & $-4.3 \pm 0.2$ & $-5.1 \pm 0.3$ \\
\hline 114 & $-5.1 \pm 0.5$ & $-4.5 \pm 0.2$ & $-5.2 \pm 0.4$ & $-4.9 \pm 0.5$ & $-4.5 \pm 0.2$ & $-5.1 \pm 0.4$ \\
\hline 152 & $-4.6 \pm 0.5$ & $-4.0 \pm 0.4$ & $-4.7 \pm 0.5$ & $-4.6 \pm 0.5$ & $-4.1 \pm 0.3$ & $-4.7 \pm 0.5$ \\
\hline$p$-value & 0.439 & 0.116 & 0.442 & 0.302 & 0.102 & 0.320 \\
\hline
\end{tabular}

${ }^{1}$ Conjugation frequency $(\mathrm{CF})$ calculated as $\mathrm{CF} / \mathrm{D}=$ transconjugants/donor, $\mathrm{CF} / \mathrm{R}=$ transconjugants/recipients or $\mathrm{CF} / \mathrm{T}=$ transconjugants/total bacterial count; SIF = stress impact factor (Supplementary data, Table S3); $p$-values were calculated comparing CF of different levels of exposure to the stressor using the nonparametric Kruskal-Wallis test and Mann-Whitney test. Significant differences $(p \leq 0.05)$ between values are indicated by different superscript letters. Raw data are provided in supplementary data, Table S1.

\section{Discussion}

The aim of this study was to investigate the impact of nutrition related stress factors on conjugation frequencies in an in vitro trial with an ESBL-producing E. coli donor strain and a Salmonella Typhimurium recipient. 
Conjugation frequency $(\mathrm{CF})$ is frequently calculated by dividing the number of transconjugants $/ \mathrm{mL}$ by the donor count per $\mathrm{mL}$ [40-45]. However, CF can also refer to the recipient instead of donor count $[12,43]$. Both donor and recipient growth are generally considered independent of each other but undergo dynamic growth states in the intestine. Therefore, this study was designed to investigate the impact of both donor and recipient, as well as the total bacterial count on conjugation frequencies. The rationale behind this approach is the view that in vivo bacteria are under constant stress, and, therefore, different stressors affect the physiological response of both donor and recipient. Thus, the results of this study differ depending on the method of calculation as they address different questions. To evaluate the risk of transmission following an infection with ESBL-producing Enterobacteriaceae, it is important to know, how many ESBL-producing E. coli cells transfer their plasmid to a potential recipient. However, the health-related risks and clinical importance of antibiotic resistant pathogens may be better characterized by their uptake of resistance genes.

The impact of different agents on conjugation events is commonly displayed as a change in CF. However, these agents do not only impact the formation of transconjugants, but also their growth and viability, as well as the growth and viability of recipient and donor. This creates a bias neglected by the common methods to calculate the $\mathrm{CF}$ as transconjugants/donor or transconjugants/recipient [14]. If the donor and recipient concentrations remain steady during a certain period of time, one may, therefore, refer instead to conjugation efficiency (Equation 4) [14,27]. This, however, did not apply for the current study and does not resemble the environment in the gastrointestinal tract, where changes in diet, treatment, or infection alter microbial composition $[4,44,45]$. Therefore, we developed a method to monitor conjugation frequencies for donor, recipient, and transconjugants under the effect of different stressors. By calculating the relative impact on growth and viability and multiplying this factor by their respective $\mathrm{cfu} / \mathrm{mL}$, all parts of the in vitro system were corrected for the growth impact of the stressor itself.

From the above it is concluded that the method of calculation has a significant impact on the results, and, thus, different methods should be considered in studies on the impact of stressors on conjugation frequency.

In the gastrointestinal tract (GIT) of poultry, $\mathrm{pH}$ levels range mainly between 5 and 8 , if gizzard and proventriculus are neglected [46,47]. The crop and caecum are the compartments with the highest bacterial density, where bacterial interaction is most likely to occur [4,5]. Therefore, these $\mathrm{pH}$ values were chosen when studying the impact of $\mathrm{pH}$ on $\mathrm{CF}$. When investigating $\mathrm{pH}$ as a stress factor, no impact on conjugation was observed in this study. Similarly, the growth of both donor and recipient strain was not significantly affected. In contrast, a positive impact on CF was observed in an experiment with an E. coli donor and a Salmonella Typhimurium recipient where an Inc GpI1 plasmid was transferred at a $\mathrm{pH}$ value of 4.3 [25]. Similar results were observed with other different $E$. coli donors and recipients [18]. Unfortunately, conjugation frequency was only based on the recipient count, and no information on the impact of the acid stress on the growth of the strains was stated. In the same study, the impact of low temperatures was investigated, showing a significantly higher impact on the conjugation rate compared to results with different $\mathrm{pH}$ values. When a combination of low temperatures and a $\mathrm{pH}$ value of 5 was tested for two different mating pairs, the effect was very similar to the impact of the low temperature alone [18]. This suggests that the $\mathrm{pH}$ of 5 did not have an impact on the conjugation, corresponding to the findings in this study. The increase of transconjugants at low $\mathrm{pH}$ levels was also observed in a study investigating the impact of $\mathrm{HCl}$ at $0.032-0.128 \mathrm{M}$ on conjugation [18]. However, no information on conjugation frequencies or donor and recipient growth at these levels was provided. Thus, very low $\mathrm{pH}$ values may have an impact on conjugation, but $\mathrm{pH}$ levels commonly observed in the major parts of the intestinal tract may not be low enough to have an influence.

Osmolality in the gastrointestinal tract of broilers varies between individual bowel segments. Accordingly, osmolalities of 540 (crop), 312 (gizzard), 571 (duodenum), 650-573 (jejunum), and 514-451 (ileum) $\mathrm{mOsm} / \mathrm{kg}$ were reported [48], descending the intestinal tract, while osmolarities of 390 (duodenum), 430 (jejunum), and 340 (ileum) mOsm/L were observed [47]. Despite the numeric 
differences between these two studies, in the small intestine, the highest values were always observed in the jejunum, followed by the duodenum and ileum. In contrast to the findings from the $\mathrm{pH}$ setup, osmolality reduced the conjugation frequency exponentially, when calculating $C F(D)$ and $C F(T)$, while a more linear reduction was observed when calculating $\mathrm{CF}(\mathrm{R})$. Similar to experiments with different $\mathrm{pH}$ values, the donor growth was not affected by increasing osmolality, while the recipient strain showed reduced growth/viability. Thus, it appears that conjugation is more likely to occur in the gizzard or ileum as far as osmolality is concerned.

Since the ban of antibiotic growth promoters in the European Union (EC (No) 1831/2003), alternatives have especially gained importance [49]. Zinc and copper are commonly used in animal production to increase health, feed efficiency, and body weight [50]. In this study, the impact of zinc and copper on conjugation was the most profound among all tested stressors. Conjugation frequencies were reduced with approximately 2.3 and $0.8 \mathrm{log}$ levels for copper and zinc respectively after correcting for stress impact on growth. Interestingly, in the zinc set up, the highest reduction occurred for medium levels of zinc supplementations contrary to experiments with copper, which showed a decreasing frequency of conjugation with increasing copper concentrations. The decrease of CF at medium zinc concentrations, followed by an increase with increasing zinc concentrations, might indicate that zinc up to a certain concentration can reduce conjugation. However, as bacterial stress increases at higher zinc concentrations, horizontal gene transfer might also be enhanced. This suggests a correlation between concentration of stressor and CF, which must not be linear. One must acknowledge that numerically, the observed decrease of CF at 321 and $642 \mu \mathrm{M} \mathrm{Zn}$ (II) is rather small $(<1 \log \mathrm{cfu} / \mathrm{mL})$, indicating that interpretations should be discussed critically. Further studies should investigate this observation in detail. Zinc acetate $(0.2 \mathrm{mM}$ zinc) reduced the transfer of an ESBL-carrying plasmid from an Enterobacter donor to an E. coli recipient under detection limit [51]. As results from this study did not show such a severe impact, it must be considered that the conjugative pair used in the present study was more prone to transfer plasmids and did so in a shorter time period. Varying conjugation frequencies were also observed for ESBL-producing Enterobacteriaceae in the presence of different metal surfaces with an E. coli and a Klebsiella pneumoniae donor and a E. coli recipient [45]. While CF declined after $2 \mathrm{~h}$ on stainless steel, it fell below the detection limit after $2 \mathrm{~h}$ incubation on the copper surface. This agrees with our results, where increasing concentrations of copper led to higher reductions of conjugation rates. Similarly, different copper supplementations of $\mathrm{CuSO}_{4}$ and copper nanoparticles reduced conjugation frequencies [52]. From this comprehensive perspective, the copper surface should be considered a substantial high concentration. A link between the usage of zinc and copper feed additives and the occurrence of antibiotic resistance was established repeatedly [53-57]. Consequently, the European Medicines Agency (EMA) and European Food Safety Authority (EFSA) recommends reducing zinc and copper in animal production [58,59]. The positive impact of copper and zinc on the reduction of CF must, therefore, be weighed against the risk of increasing prevalence of antibiotic resistant bacteria by other mechanisms and treatments.

Bacterial metabolites may also have an impact on bacterial physiology in vivo. For instance, a reduction of conjugation frequency was previously reported in the presence of lactic acid producing bacteria, such as Streptococcus thermophilus, Lactobacillus fermentum, Lactobacillus plantarum, and Lactobacillus bulgaricus [19,60-63]. This effect was assumed to be due to their lactate production among other factors. This hypothesis could not be confirmed here, as lactate did not lead to a reduced conjugation frequency. Interestingly, while numeric differences between the control and highest lactate concentrations were negligible, n-butyrate actually showed higher conjugation rates at its highest concentration, while acetate numerically decreased the conjugation frequency. Thus, apart from $\mathrm{pH}$ reduction, bacterial metabolites may also play different roles for the transfer of mobile genetic elements. This may also be the case for propionic acid, which showed a negative concentration dependent effect on conjugation. Similarly, a reduction of CF(D) was observed in an experiment with Salmonella enterica serovar Typhimurium donor and recipient strains derived from mice in the presence of propionate [64]. As $\mathrm{pH}$ as a factor can be ruled out, and the growth corrected conjugation frequency also declined 
drastically, it can be concluded that propionate acts differently on conjugation than acetate or n-butyrate. Finally, observed effects for propionate were only significant at concentrations that exceeded the usually observed threshold in the hindgut of poultry. However, propionate is used in quite high doses for its antibacterial and antifungal properties in animal nutrition, and, therefore, further in vivo studies should investigate the effect of propionic acid as a feed additive to counteract the transfer of ESBL-carrying plasmids in Enterobacteriaceae.

The determined conjugation frequency depends on two factors-The bacterial concentration and the transconjugants' growth. The bacterial concentration shapes the chance for donor and recipients to meet close enough to perform a plasmid transfer. On the other hand, transconjugant growth directly affects the number of detected transconjugants and thus the calculation and result of CF. Hence, it would be tempting to conclude that changes in CF can be explained solely mathematically due to variations of donor, recipient, and/or transconjugant concentrations in the presence of stressors. To investigate this further, an experiment with sublethal amounts of antibiotics was designed, to reduce the growth of (a) donor, (b) recipient, or (c) both donor and recipient. Assuming that conjugation comes at no fitness cost or gain, the transconjugants should grow similar to the recipients, as they are basically identical apart from their additional plasmid harboring resistance against CTX. If the explanation for the changes in CF were solely mathematical, the following situation would arise for the mentioned scenarios:

a. Lower numbers of donor cells would lead to a higher ratio of transconjugants per donor cell count.

b. Lower numbers of recipient cells would lead to lower numbers of transconjugants and a decreased ratio of transconjugants per donor cell count (except for CTX supplementation, as the transconjugants grow better than the recipients).

c. As recipient and donor are affected equally, CF will not differ significantly from control.

This would lead to a lower number of transconjugants per donor in the osmolality and CTX experiments. This effect should be more profound for osmolality, since both the recipient count and transconjugant growth are affected negatively. CTX, on the other hand, reduces the growth of the recipient more than transconjugant growth. Thus, one expects decreasing $C F(D), C F(R)$, and $C F(T)$ with increasing concentrations of CTX and higher osmolality. Similarly, SXT supplementation would result in an increase of transconjugants per donor and higher $C F(D)$, while lower $C F(R)$ would be expected at increasing antibiotic concentration. Nitrofurantoin inhibited the growth of donors and recipients in an equal manner. Therefore, no significant differences were predicted. The results from the experiments differed from these assumptions. Thus, the changes in conjugation frequencies cannot solely be explained by changes in bacterial growth, justifying the conclusion that some stress factors may directly influence conjugation.

Antibiotics are frequently used in livestock as therapeutics, meta- and prophylaxis and, outside the European Union, in subtherapeutic levels to enhance performance $[5,10,65]$. The usage of antibiotics always comes with the risk of developing antibiotic resistant bacteria due to selective pressure, especially when used at subtherapeutic levels $[5,10,66]$. Simultaneously, the potential threat to survival is posing stress to the microorganisms resulting in changes of metabolism and activity $[24,36,37]$. This may also impact conjugation [35]. The influence of gentamycin on the transfer of an ESBL-carrying plasmid from an E. coli donor to E. coli and Pseudomonas aeruginosa recipients had similar prerequisites as the CTX experiment, since donor growth was not affected as much as the recipient, which declined with increasing concentrations [67]. Similar results were observed in a further study investigating the impact of three different antibiotics in a conjugation experiment with resistant donors and transconjugants but sensitive recipients [68]. Pseudomonas aeruginosa accepted the ESBL-carrying plasmids at a higher rate only at a state where the antibiotic concentration changed from low impact to high impact on recipient growth. The results agree with the results from the CTX experiment $(\mathrm{CF}(\mathrm{D}))$. In the case of the E. coli recipient, $\mathrm{CF}(\mathrm{D})$ decreased with increasing gentamycin [68] supplementation, corresponding with the results from the presented nitrofurantoin experiment. However, nitrofurantoin had a different impact 
on donor growth. The gentamycin effect was observed at a stage of severe impact on recipient growth, and this was not considered when CF was calculated. Thus, the low detection of transconjugants may be the reason for these results, rather than an actual change in conjugation. Similar to the nitrofurantoin experiment, it was previously described that an antibiotic substance, affecting donors and recipients equally, may lead to a reduction of conjugation frequencies [68]. The impact of antibiotics on donor, recipient, and transconjugant growth over a period of time shows how incorrect assumptions on the impact of different factors easily arise [20]. Even after recipient counts fell under the detection limit, transconjugants kept rising. Simultaneously, the ratio of transconjugants/donor and transconjugant/recipient changed with time. Both amoxicillin and ampicillin reduced transconjugant counts similar to the cefotaxime experiment with increasing antibiotic concentrations [20]. CF(D) increased in the presence of sulfamethoxazole/trimethoprim. However, when corrected for growth impact, the effect was opposite, showing a significant decrease in conjugation frequency with an increasing concentration of SXT, which was also observed for $\mathrm{CF}(\mathrm{R})(\mathrm{SIF})$ and $\mathrm{CF}(\mathrm{T})(\mathrm{SIF})$.

\section{Conclusions}

In conclusion, a negative impact on conjugation frequency was observed for osmolality, zinc, copper, and propionic acid, as well as subtherapeutic levels of antibiotics. No effects were found for $\mathrm{pH}$ or the bacterial metabolites lactate, acetate, or n-butyrate. Furthermore, no stressors increased conjugation frequency, and, thus, the hypothesis that stress generally increases bacterial conjugation should be viewed with caution. The results also show that, in studies focusing on stress related effects on gene transfer, the calculation of conjugation frequency should include the impact of a stressor on donor, recipient, and transconjugant. Still, it must be considered that the observed impact on conjugation frequencies might be strain specific. Future studies should, therefore, investigate if these observations can be repeated with different donor and recipient strains. In the present study, the impact on conjugation events was investigated for one stressor at a time. However, the intestinal tract of broilers combines these and further stressors. Thus, further studies should be anticipated to examine conjugation events in complex systems.

Supplementary Materials: The following are available online at http://www.mdpi.com/2218-273X/9/8/324/s1, Figure S1: Bacterial concentration at different $\mathrm{pH}$ values, Figure S2: Bacterial concentration at different osmolalities, Figure S3: Bacterial concentration at different levels of cefotaxime (CTX), Figure S4: Bacterial concentration at different levels of sulfamethoxazole/trimethoprim (SXT), Figure S5: Bacterial concentration at different levels of nitrofurantoin (F), Figure S6: Bacterial concentration at different levels of copper, Figure S7: Bacterial concentration at different levels of zinc, Figure S8: Bacterial concentration at different concentrations of acetate, Figure S9: Bacterial concentration at different concentrations of D/L-lactate, Figure S10: Bacterial concentration at different concentrations of propionate, Figure S11: Bacterial concentration at different concentrations of n-butyrate, Table S1: Conjugation frequencies: measured values, Table S2: Bacterial growth: measured values, Table S3: Values of stress impact factor.

Author Contributions: E.-M.S. planned and carried out the experiment and wrote the manuscript with input from all authors. M.E. designed the technical details for the osmolality, zinc, copper and $\mathrm{pH}$ media. W.V., J.Z., and E.-M.S. conceived the original idea. W.V. supervised the project. J.Z. helped to supervise the project. All authors discussed the results and commented on the manuscript.

Funding: E-M.S. received the Elsa Neumann scholarship for parts of the research work presented in this study. The Study was conducted within the EsRAM project, funded by the German Federal Ministry of Food and Agriculture. The publication of this article was funded by Freie Universität Berlin.

Acknowledgments: The authors want to thank Christa Ewers (Institute for Hygiene and Infectious Diseases of Animals, Justus-Liebig-Universität Gießen, Germany), and Uwe Rösler (Institute for Animal Hygiene and Environmental Health, Freie Universität Berlin, Germany) for providing the donor strain. We also want to thank Anett Kriesten, Luisa Ebersbach and Jonathan Riedmueller for excellent technical assistance.

Conflicts of Interest: The authors declare no conflict of interest.

\section{References}

1. WHO. Global Priority List of Antibiotic-Resistant Bacteria to Guide Research, Discovery, and Development of New Antibiotics; WHO: Geneva, Switzerland, 2017. 
2. Urumova, V. Extended spectrum beta lactamase producing animal enterobacteriaceae isolates as potential risk to public health-Review. Rev. Med. Vet. 2015, 166, 192-207.

3. Saliu, E.M.; Vahjen, W.; Zentek, J. Types and prevalence of extended-spectrum beta-lactamase producing Enterobacteriaceae in poultry. Anim. Health Res. Rev. 2017, 18, 46-57. [CrossRef]

4. Rehman, H.U.; Vahjen, W.; Awad, W.A.; Zentek, J. Indigenous bacteria and bacterial metabolic products in the gastrointestinal tract of broiler chickens. Arch. Anim. Nutr. 2007, 61, 319-335. [CrossRef]

5. Yeoman, C.J.; Chia, N.; Jeraldo, P.; Sipos, M.; Goldenfeld, N.D.; White, B.A. The microbiome of the chicken gastrointestinal tract. Anim. Health Res. Rev. 2012, 13, 89-99. [CrossRef]

6. Carattoli, A. Plasmids and the spread of resistance. Int. J. Med. Microbiol. 2013, 303, 298-304. [CrossRef]

7. Ferrario, C.; Alessandri, G.; Mancabelli, L.; Gering, E.; Mangifesta, M.; Milani, C.; Lugli, G.A.; Viappiani, A.; Duranti, S.; Turroni, F.; et al. Untangling the cecal microbiota of feral chickens by culturomic and metagenomic analyses. Environ. Microbiol. 2017, 19, 4771-4783. [CrossRef]

8. Smet, A.; Rasschaert, G.; Martel, A.; Persoons, D.; Dewulf, J.; Butaye, P.; Catry, B.; Haesebrouck, F.; Herman, L.; Heyndrickx, M. In situ ESBL conjugation from avian to human Escherichia coli during cefotaxime administration. J. Appl. Microbiol. 2011, 110, 541-549. [CrossRef]

9. Apata, D.F. Antibiotic resistance in poultry. Int. J. Poult. Sci. 2009, 8, 404-408. [CrossRef]

10. Landers, T.F.; Cohen, B.; Wittum, T.E.; Larson, E.L. A review of antibiotic use in food animals: Perspective, policy, and potential. Public Health Rep. 2012, 127, 4-22. [CrossRef]

11. Winokur, P.L.; Vonstein, D.L.; Hoffman, L.J.; Uhlenhopp, E.K.; Doern, G.V. Evidence for transfer of CMY-2 AmpC beta-lactamase plasmids between Escherichia coli and Salmonella isolates from food animals and humans. Antimicrob. Agents Chemother. 2001, 45, 2716-2722. [CrossRef]

12. Cottell, J.L.; Webber, M.A.; Piddock, L.J. Persistence of Transferable Extended-Spectrum-beta-Lactamase Resistance in the Absence of Antibiotic Pressure. Antimicrob. Agents Chemother. 2012, 56, 4703-4706. [CrossRef]

13. Norman, A.; Hansen, L.H.; Sorensen, S.J. Conjugative plasmids: Vessels of the communal gene pool. Philos. Trans. R. Soc. Lond. B Biol. Sci. 2009, 364, 2275-2289. [CrossRef]

14. Lopatkin, A.J.; Sysoeva, T.A.; You, L. Dissecting the effects of antibiotics on horizontal gene transfer: Analysis suggests a critical role of selection dynamics. Bioessays 2016, 38, 1283-1292. [CrossRef]

15. Yamaichi, Y.; Chao, M.C.; Sasabe, J.; Clark, L.; Davis, B.M.; Yamamoto, N.; Mori, H.; Kurokawa, K.; Waldor, M.K. High-resolution genetic analysis of the requirements for horizontal transmission of the ESBL plasmid from Escherichia coli O104:H4. Nucleic Acids Res. 2015, 43, 348-360. [CrossRef]

16. Franiczek, R.; Krzyzanowska, B. ESBL-Producing Escherichia coli Isolated from Bloodstream Infections-Antimicrobial Susceptibility, Conjugative Transfer of Resistance Genes and Phylogenetic Origin. Adv Clin. Exp. Med. 2014, 23, 865-870. [CrossRef]

17. Franiczek, R.; Dolna, I.; Krzyzanowska, B.; Szufnarowski, K.; Kowalska-Krochmal, B. Conjugative transfer of multiresistance plasmids from ESBL-positive Escherichia coli and Klebsiella spclinical isolates to Escherichia coli strain K12C600. Adv. Clin. Exp. Med. 2007, 16, 239-247.

18. Schafer, A.; Kalinowski, J.; Puhler, A. Increased fertility of Corynebacterium glutamicum recipients in intergeneric matings with Escherichia coli after stress exposure. Appl. Environ. Microbiol. 1994, 60, 756-759.

19. Maisonneuve, S.; Ouriet, M.; Duval-Iflah, Y. Effects of yoghurt intake on plasmid transfer and colonisation with transconjugants in the digestive tract of mice associated with human faecal flora. FEMS Microbiol. Ecol. 2000, 31, 241-248. [CrossRef]

20. Händel, N.; Otte, S.; Jonker, M.; Brul, S.; ter Kuile, B.H. Factors That Affect Transfer of the IncI1 beta-Lactam Resistance Plasmid pESBL-283 between E-coli Strains. PLoS ONE 2015, 10, e0123039. [CrossRef]

21. Lim, S.; Cho, S.; Caetano-Anolles, K.; Jeong, S.G.; Oh, M.H.; Park, B.Y.; Kim, H.J.; Cho, S.; Choi, S.H.; Ryu, S.; et al. Developmental Dynamic Analysis of the Excreted Microbiome of Chickens Using Next-Generation Sequencing. J. Mol. Microbiol. Biotechnol. 2015, 25, 262-268. [CrossRef]

22. Den Hartog, G.; De Vries-Reilingh, G.; Wehrmaker, A.M.; Savelkoul, H.F.J.; Parmentier, H.K.; Lammers, A. Intestinal immune maturation is accompanied by temporal changes in the composition of the microbiota. Benef Microbes 2016, 7, 677-685. [CrossRef]

23. Sarowska, J.; Drulis-Kawa, Z.; Guz, K.; Jankowski, S.; Wojnicz, D. Conjugative Transfer of Plasmid Encoding Extended-Spectrum Beta-Lactamase to Recipient Salmonella Strains. Adv. Clin. Exp. Med. 2009, 18, 63-70. 
24. Boor, K.J. Bacterial stress responses: What doesn't kill them can make them stronger. PLoS Biol. 2006, 4, 18-20. [CrossRef]

25. Mc Mahon, M.A.S.; Blair, I.S.; Moore, J.E.; Mc Dowell, D.A. The rate of horizontal transmission of antibiotic resistance plasmids is increased in food preservation-stressed bacteria. J. Appl. Microbiol. 2007, 103, 1883-1888. [CrossRef]

26. Xi, M.; Wu, Q.; Wang, X.; Yang, B.; Xia, X.; Li, D. Characterization of Extended-Spectrum beta-Lactamase-Producing Escherichia coli Strains Isolated from Retail Foods in Shaanxi Province, China. J. Food Prot. 2015, 78, 1018-1023. [CrossRef]

27. Lopatkin, A.J.; Huang, S.; Smith, R.P.; Srimani, J.K.; Sysoeva, T.A.; Bewick, S.; Karig, D.K.; You, L. Antibiotics as a selective driver for conjugation dynamics. Nat. Microbiol. 2016, 1, 16044. [CrossRef]

28. Al-Masaudi, S.B.; Day, M.J.; Russell, A.D. Effect of some antibiotics and biocides on plasmid transfer in Staphylococcus aureus. J. Appl. Bacteriol. 1991, 71, 239-243. [CrossRef]

29. Kiarie, E.; Romero, L.F.; Nyachoti, C.M. The role of added feed enzymes in promoting gut health in swine and poultry. Nutr. Res. Rev. 2013, 26, 71-88. [CrossRef]

30. Czerwiński, J.; Hojberg, O.; Smulikowska, S.; Engberg, R.M.; Mieczkowska, A. Influence of dietary peas and organic acids and probiotic supplementation on performance and caecal microbial ecology of broiler chickens. Br. Poult. Sci. 2010, 51, 258-269. [CrossRef]

31. Oliveira, P.C.; Silva, J.A.; Siqueira-Junior, J. Nature of the antimicrobial activity of Lactobacillus caseiBifidobacterium bifidum and Bifidobacterium animalis against foodborne pathogenic and spoilage microorganisms. Nat. Prod. Res. 2015, 29, 2133-2136. [CrossRef]

32. Gaggia, F.; Mattarelli, P.; Biavati, B. Probiotics and prebiotics in animal feeding for safe food production. Int. J. Food Microbiol. 2010, 141 (Suppl. 1), S15-S28.

33. Chaucheyras-Durand, F.; Durand, H. Probiotics in animal nutrition and health. Benef. Microbes 2010, 1, 3-9. [CrossRef]

34. Andreopoulou, M.; Tsiouris, V.; Georgopoulou, I. Effects of organic acids on the gut ecosystem and on the performance of broiler chickens. J. Hell. Vet. Med Soc. 2014, 65, 289-302. [CrossRef]

35. Poole, K. Bacterial stress responses as determinants of antimicrobial resistance. J. Antimicrob. Chemother. 2012, 67, 2069-2089. [CrossRef]

36. Marles-Wright, J.; Lewis, R.J. Stress responses of bacteria. Curr. Opin. Struct. Biol. 2007, 17, 755-760. [CrossRef]

37. Aertsen, A.; Michiels, C.W. Stress and how bacteria cope with death and survival. Crit. Rev. Microbiol. 2004, 30, 263-273. [CrossRef]

38. Saliu, E.; Zentek, Z.; Vahjen, W. In vitro conjugation kinetics of ESBL-producing Escherichia coli donors and various Enterobacteriaceae recipients. 2019. manuscript submitted for publication.

39. Liedtke, J.; Vahjen, W. In vitro antibacterial activity of zinc oxide on a broad range of reference strains of intestinal origin. Vet. Microbiol. 2012, 160, 251-255. [CrossRef]

40. Cottell, J.L.; Saw, H.T.; Webber, M.A.; Piddock, L.J. Functional genomics to identify the factors contributing to successful persistence and global spread of an antibiotic resistance plasmid. BMC Microbiol. 2014, 14, 168. [CrossRef]

41. Nilsen, E.; Haldorsen, B.C.; Sundsfjord, A.; Simonsen, G.S.; Ingebretsen, A.; Naseer, U.; Samuelsen, Ø.; Norwegian Study Group on Invasive Enterobacter. Large IncHI2-plasmids encode extended-spectrum beta-lactamases (ESBLs) in Enterobacter spbloodstream isolates, and support ESBL-transfer to Escherichia coli. Clin. Microbiol. Infect. 2013, 19, E516-E518. [CrossRef]

42. Warnes, S.L.; Highmore, C.J.; Keevil, C.W. Horizontal Transfer of Antibiotic Resistance Genes on Abiotic Touch Surfaces: Implications for Public Health. MBio 2012, 3, e00489-12. [CrossRef] [PubMed]

43. Mugnaioli, C.; Luzzaro, F.; De Luca, F.; Brigante, G.; Amicosante, G.; Rossolini, G.M. Dissemination of CTX-M-type extended-spectrum beta-lactamase genes to unusual hosts. J. Clin. Microbiol. 2005, 43, 4183-4185. [CrossRef] [PubMed]

44. Torok, V.A.; Allison, G.E.; Percy, N.J.; Ophel-Keller, K.; Hughes, R.J. Influence of Antimicrobial Feed Additives on Broiler Commensal Posthatch Gut Microbiota Development and Performance. Appl. Environ. Microbiol. 2011, 77, 3380-3390. [CrossRef] [PubMed]

45. Pan, D.; Yu, Z. Intestinal microbiome of poultry and its interaction with host and diet. Gut Microbes 2014, 5, 108-119. [CrossRef] [PubMed] 
46. Mabelebele, M.; Alabi, O.J.; Ngambi, J.W.; Norris, D.; Ginindza, M.M. Comparison of Gastrointestinal Tracts and $\mathrm{pH}$ Values of Digestive Organs of Ross 308 Broiler and Indigenous Venda Chickens Fed the Same Diet. Asian J. Anim. Vet. Adv. 2014, 9, 71-76. [CrossRef]

47. Mitchell, M.A.; Lemme, A. Examination of the Composition of the Luminal Fluid in the Small Intestine of Broilers and Absorption of Amino Acids under Various Ambient Temperatures Measured In vivo. Int. J. Poult. Sci. 2008, 7, 223-233.

48. Mongin, P.; Larbier, M.; Baptista, N.C.; Licois, D.; Coudert, P. A comparison of the osmotic pressures along the digestive tract of the domestic fowl and the rabbit. Br. Poult. Sci. 1976, 17, 379-382. [CrossRef] [PubMed]

49. Regulation (EC) No 1831/2003 of the European Parliament and of the Council of 22 September 2003 on Additives for Use in Animal Nutrition; chapter II, article 11.

50. El-Hack, M.A.; Alagawany, M.; Arif, M.; Chaudhry, M.T.; Emam, M.; Patra, A. Organic or inorganic zinc in poultry nutrition: A review. World Poult. Sci. J. 2017, 73, 904-915. [CrossRef]

51. Crane, J.K.; Cheema, M.B.; Olyer, M.A.; Sutton, M.D. Zinc Blockade of SOS Response Inhibits Horizontal Transfer of Antibiotic Resistance Genes in Enteric Bacteria. Front Cell Infect. Microbiol. 2018, 8, 410. [CrossRef]

52. Parra, B.; Tortella, G.R.; Cuozzo, S.; Martínez, M. Negative effect of copper nanoparticles on the conjugation frequency of conjugative catabolic plasmids. Ecotoxicol. Environ. Saf. 2019, 169, 662-668. [CrossRef]

53. Hasman, H.; Aarestrup, F.M. tcrB gene conferring transferable copper resistance in Enterococcus faecium: Occurrence, transferability, and linkage to macrolide and glycopeptide resistance. Antimicrob. Agents Chemother. 2002, 46, 1410-1416. [CrossRef] [PubMed]

54. Kappes, T.; Dominguez, M.; Bello, H.; Mella, S.; Riedel, G.; Gonzalez-Rocha, G. Copper activity against multiresistant Gram negative bacilli isolated from Chilean hospitals. Rev. Chilena Infectol. 2012, 29, $622-627$. [CrossRef] [PubMed]

55. Aarestrup, F.M.; Cavaco, L.; Hasman, H. Decreased susceptibility to zinc chloride is associated with methicillin resistant Staphylococcus aureus CC398 in Danish swine. Vet. Microbiol. 2010, 142, 455-457. [CrossRef] [PubMed]

56. Bednorz, C.; Oelgeschläger, K.; Kinnemann, B.; Hartmann, S.; Neumann, K.; Pieper, R.; Bethe, A.; Semmler, T.; Tedin, K.; Schierack, P.; et al. The broader context of antibiotic resistance: zinc feed supplementation of piglets increases the proportion of multi-resistant Escherichia coli in vivo. Int. J. Med. Microbiol. 2013, 303, 396-403. [CrossRef] [PubMed]

57. Vahjen, W.; Pietruszyńska, D.; Starke, I.C.; Zentek, J. High dietary zinc supplementation increases the occurrence of tetracycline and sulfonamide resistance genes in the intestine of weaned pigs. Gut Pathog. 2015, 7, 23. [CrossRef] [PubMed]

58. EFSA. Reviews Maximum Content of Copper in Animal Feed. Available online: https://www.efsa.europa.eu/ en/press/news/160809-0 (accessed on 20 June 2019).

59. Committee for Medicinal Products for Veterinary Use (CVMP). Meeting of 14-16 March 2017. Available online: https://www.ema.europa.eu/en/news/committee-medicinal-products-veterinary-use-cvmp-meeting14-16-march-2017 (accessed on 20 June 2019).

60. Tallmeister, E.T.; Lentsner, K.; Lentsmer, A.A. Effect of lactic bacteria metabolic products on the transmission of R-plasmids in enterobacteria in vitro. Zh. Mikrobiol. Epidemiol. Immunobiol. 1977, 8, 69-73.

61. Sabia, C.; de Niederhäusern, S.; Guerrieri, E.; Bondi, M.; Anacarso, I.; Iseppi, R.; Messi, P. Interference of Lactobacillus plantarum strains in the in vitro conjugative transfer of R-plasmids. Curr. Microbiol. 2009, 58, 101-105. [CrossRef] [PubMed]

62. Maisonneuve, S.; Ouriet, M.F.; Duval-Iflah, Y. Comparison of yoghurt, heat treated yoghurt, milk and lactose effects on plasmid dissemination in gnotobiotic mice. Antonie Van Leeuwenhoek 2001, 79, 199-207. [CrossRef]

63. Maisonneuve, S.; Ouriet, M.F.; Duval-Iflah, Y. Interrelationships between dairy product intake, microflora metabolism, faecal properties and plasmid dissemination in gnotobiotic mice. Br. J. Nutr. 2002, 87, 121-129. [CrossRef]

64. García-Quintanilla, M.; Ramos-Morales, F.; Casadesús, J. Conjugal transfer of the Salmonella enterica virulence plasmid in the mouse intestine. J. Bacteriol. 2008, 190, 1922-1927. [CrossRef]

65. Van Boeckel, T.P.; Brower, C.; Gilbert, M.; Grenfell, B.T.; Levin, S.A.; Robinson, T.P.; Teillant, A.; Laxminarayan, R. Global trends in antimicrobial use in food animals. Proc. Natl. Acad. Sci. USA 2015, 112, 5649-5654. [CrossRef] [PubMed] 
66. Marshall, B.M.; Levy, S.B. Food Animals and Antimicrobials: Impacts on Human Health. Clin. Microbiol. Rev. 2011, 24, 718-733. [CrossRef] [PubMed]

67. Lu, Y.; Zeng, J.; Wang, L.; Lan, K.; Shunmei, E.; Wang, L.; Xiao, Q.; Luo, Q.; Huang, X.; Huang, B.; et al. Antibiotics Promote Escherichia coli-Pseudomonas aeruginosa Conjugation through Inhibiting Quorum Sensing. Antimicrob. Agents Chemother. 2017, 61, e01284-17. [CrossRef] [PubMed]

68. Headd, B.; Bradford, S.A. Physicochemical Factors That Favor Conjugation of an Antibiotic Resistant Plasmid in Non-growing Bacterial Cultures in the Absence and Presence of Antibiotics. Front. Microbiol. 2018, 9, 2122. [CrossRef] [PubMed]

(C) 2019 by the authors. Licensee MDPI, Basel, Switzerland. This article is an open access article distributed under the terms and conditions of the Creative Commons Attribution (CC BY) license (http://creativecommons.org/licenses/by/4.0/). 